Social, and Cultural Rights (ICESCR), which most countries have ratified, although the United States has not. The ICCPR does not subject the right to hold opinions to any restriction, while freedom of expression can be curtailed only on specified grounds, such as protection of public order or national security, through legal measures that are deemed necessary. The covenant therefore subjects academic freedom to restrictions similar to those imposed by U.S. law. For example, the United States could legitimately discriminate against noncitizens under the ICCPR and prevent the application of Article 19 to private educational institutions. For noncitizen scholars working in the United States, this does not provide extra protection.

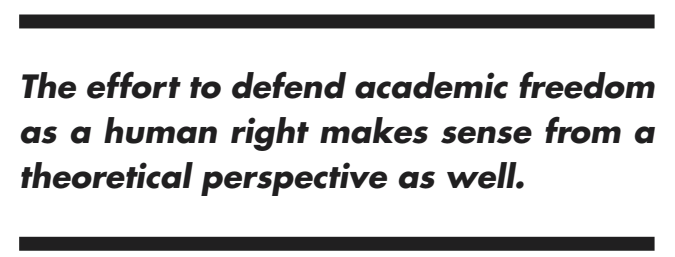

In 1999, through the ICESCR, the United Nations recognized academic freedom as part of a human right to education. As the organization's Committee on Economic, Social, and Cultural Rights stressed, the "right to education can only be enjoyed if accompanied by the academic freedom of staff and students." The committee further emphasized that, in its experience, "staff and students in higher education are especially vulnerable to political and other pressures which undermine academic freedom." This approach-recognition of the importance of core civil and political rights, such as academic freedom, for the protection of economic, social, and cultural rights such as education-is an interesting and innovative way to defend academic freedom. Unfortunately, the covenant does not mention in any detail issues such as individual academic freedom, university autonomy, or the right of members of academic institutions to participate in self-governance. Such matters are left for the jurisprudence of the committee.

The effort to defend academic freedom as a human right makes sense from a theoretical perspective as well. There are at least two ways to understand academic freedom. One is as an individual right, a collection of all the expressive freedoms that any member of the academic community has as an individual, including the rights to free expression, opinion, and association. This view defines academic freedom as a subset of a larger category that needs no special protection. The United States, where academic freedom is subsumed under the First Amendment, takes this approach, as does South Africa, where the constitution mentions it as part of the right to free expression.
A second way to think about academic freedom is as a right to education that has individual and collective dimensions that can only be discharged through complex relationships between students, faculty, institutions, the government, and the society. In this sense, academic freedom is not only an end, as it is under an individualistic conception. It is also the means for realizing other important ends, including individual freedoms that go beyond expressive freedoms to encompass all freedoms such as nondiscrimination. The ICESCR expressly states that education "shall be directed to the full development of the human personality."

Indeed, a human right to education injects an ethical dimension into academic freedom by broadening the objectives of education. That is, academic freedom exists so that individual professors and their institutions can pursue important educational objectives. Conversely, the right to academic freedom can be defended as an essential part of a right to education. In other words, academic freedom is not simply an individual right to something, but it is also a collective right for the realization of important societal goals. In our global age, these goals are themselves global, embodied in the idea of human rights.

A different version of this article appeared in Academe, the journal of the American Association of University Professors.

\section{The Costs and Benefits of World-Class Universities}

\section{Philip G. Altbach}

Philip G. Altbach is Monan professor of higher education and director of the Center for International Higher Education at Boston College.

- veryone wants a world-class university. No country

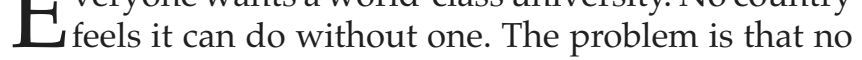
one knows what a world-class university is, and no one has figured out how to get one. Everyone, however, refers to the concept. A Google search, for example, produces thousands of references, and many institutions call themselves "world class" — from relatively modest academic universities in central Canada to a new college in the Persian Gulf. This is an age of academic hype, with universities of different kinds and in diverse countries claiming the exalted status of world class-generally with little justification. Those seeking to certify "world classness" generally do not know what they are talking about. For example, Asiaweek, a respected Hong Kongbased magazine produced a ranking of Asian universities for several years until their efforts were so widely 
criticized that they stopped. This article attempts the impossible- to define a world-class university, and then to argue that it is just as important for academic institutions to be "national" or "regional class" rather than to seek to emulate the wealthiest and in many ways most elitist universities.

This article attempts the impossible-to define a world class university.

Charles W. Eliot, president of Harvard for almost 40 years in the late 19th century, when asked by John D. Rockefeller what it would take to create the equivalent of a world-class university, responded that it would require $\$ 50$ million and 200 years. He was wrong. At the beginning of the 20th century, the University of Chicago became a world-class institution in two decades and slightly more than $\$ 50$ million-donated at the time by Rockefeller himself. The price has ballooned, not only because of inflation but because academic institutions have become immensely more complex and expensive. The competition has also become much fiercer. Now, it might take more than $\$ 500$ million along with clever leadership and much good luck.

There are not many world-class universities. Higher education is stratified and differentiated. We are concerned here only with the tiny pinnacle of institutions seeking to be at the top of national and international systems of higher education. In the United States, the number of top universities is small. The Association of American Universities, generally seen to be the club of the elite, has just over 50 member universities (many of which are not world class), a number that has grown only modestly since it was established in the early 20th century-out of a total of more than 3,500 academic institutions. Even in the United States, very few universities have managed to claw their way up to the top echelons. In other countries, the number of top-tier institutions is also limited, even when, as in Germany, all universities are basically treated the same in terms of budgets and mission by the government. The most elite universities are located in a small number of countries-in the mid-1980s, the Asian Wall Street Journal listed among the top 10 only 4 not in the United States (Cambridge and Oxford, Paris-Sorbonne, and Tokyo).

It is, of course, the judgment of others that carries a university into the rarified ranks of world-class institutions, and no one has figured out how to conduct an appropriate international evaluation. We do not provide such guidelines here, but this discussion may be the first step toward at least developing relevant criteria.

\section{Definitions}

Few have attempted to define a world-class university. The following characteristics are by no means agreed upon by teams of experts-this is an effort to create some benchmarks that will provide the basis for debate and analysis. The dictionary defines world class as "ranking among the foremost in the world; of an international standard of excellence." Fair enough, but in higher education, who decides? We can at least point to some relevant characteristics necessary for world-class status.

Excellence in research underpins the idea of world class-research that is recognized by peers and that pushes back the frontiers of knowledge. Such research can be measured and communicated. But if research is the central element, other aspects of a university are required to make outstanding research possible. Topquality professors are, of course, central. And to attract and retain the best academic staff, favorable working conditions must be available. These include arrangements for job security-many countries call it tenure-and appropriate salaries and benefits, although academics do not necessarily expect top salaries. The best professors see their work as a "calling" — something to which they are committed by intellectual interest and not just a job.

\section{Excellence in research underpins the idea of world class-research that is recognized by peers and that pushes back the frontiers of knowledge.}

Academic freedom and an atmosphere of intellectual excitement is central to a world-class university. This means that professors and students must be free to pursue knowledge wherever it leads and to publish their work freely without fear of sanction by either academic of external authority. Some countries permit unfettered academic freedom in the nonpolitical hard sciences, but place restrictions on it in the more sensitive social sciences and humanities. In most countries, academic freedom also extends to expression of opinions by members of the academic community on social and political issues as well as within the narrow confines of professional expertise.

The governance of the institution is also important. World-class universities have a significant measure of internal self-governance and an entrenched tradition, usually buttressed by statutes, ensuring that the academic community (usually professors, but sometimes including students) has control over the central elements of academic life-the admission of students, the 
curriculum, the criteria for the award of degrees, the selection of new members of the professoriate, and the basic direction of the academic work of the institution.

Adequate facilities for academic work are essentialthe most advanced and creative research and the most innovative teaching must have access to appropriate libraries and laboratories, as well as to the Internet and other electronic resources. With the increasing complexity and expansion of science and scholarship, the cost of providing full access becomes ever higher. While the Internet has meant some cost savings and has eased access to many kinds of knowledge, it is by no means a panacea. Facilities go beyond labs and libraries-staff and students must have adequate offices as well.

\section{Academic freedom and an atmosphere of intellectual excitement is central to a world-class university.}

Finally, and central to the academic enterprise, adequate funding must be available to support the research and teaching as well as the other functions of the university. Not only is maintaining a complex academic institution expensive, support must be consistent and long-term. The cost of maintaining a research university continues to grow because of the increasing complexity and cost of scientific research. Universities cannot benefit from many of the productivity increases due to automation - teaching and learning still generally require professors and students in direct contact. Funding is a special challenge in the present environment because governments are disinvesting in higher education in many countries. Academic institutions are everywhere asked to pay for an increasing part of their budgets through tuition and fees to students, generating funds by consulting and selling research-based products, and other revenue generating activities. The fact is that public support is necessary for research universities everywhere. Only in the United States and to a lesser extent Japan do private research universities of the highest rank exist. And in the United States there are significant government subsidies through government research grants and access to loans and grants to students. The top private institutions have significant endowments as well. The American tax system, which provides for tax-free donations to nonprofit institutions such as universities, is a major factor in permitting the growth of world-class private universities. Research universities have the ability to generate significant funds through a variety of means, but there is no substitute for consistent and substantial public financial support. Without it, developing and sustaining a world-class universities is impossible.

\section{Caveats}

A realistic and objective perspective is needed when thinking about world-class institutions of higher learning. For most countries, even large and relatively wealthy ones, only one or two world-class universities are possible or even desirable. For many countries, a world-class university is beyond the ability of the nation to support. Research universities are at the pinnacle of a differentiated academic system in a country-the rest of the system is just as important as its top.

Even the best universities are not the best in everything. Harvard does not rank at the top in engineering, for example. It might be more appropriate for many countries and institutions to focus on building world-class departments, institutes, or schoolsespecially in fields that are of special relevance to the national or regional economy or society. For example, Malaysia has focused on such disciplines are informatics and rubber technology, areas that are important to the local economy. A small number of highly ranked institutions are somewhat specialized. For example, the California Institute of Technology is a small university focusing almost exclusively on the sciences, yet it ranks fourth in the United States according to U.S. News and World Report. The Indian Institutes of Technology, which specialize in limited fields, are highly regarded in India and internationally. At the same time, these institutions provide educational opportunities in a wide range of disciplines, permitting students to choose and ensuring the possibility of interdisciplinary work.

\section{A realistic and objective perspective is needed when thinking about world- class institutions of higher learning.}

No one has figured out how to rank universities internationally, or even within countries in ways that are acceptable to the academic community or that can withstand serious critiques. There are many rankings of academic institutions-and these generally emphasize the characteristics relating to research university status. Yet, few of these have been conducted by official organizations or reputable research organizations. Newspapers or magazines have done most and, as noted, only a few are taken seriously. Thus, we have neither national rankings 
that make sense nor a widely accepted definition of what a world-class university is so that such an institution can be recognized or, for that matter, aspired to. It is not enough to quote what U.S. Supreme Court Justice Potter Stewart said about pornography, "I know it when I see it."

\section{Overemphasizing attaining world-class status may harm an individual univer- sity or an academic system.}

\section{Overemphasis}

Overemphasizing attaining world-class status may harm an individual university or an academic system. It may divert energy and resources from more important-and perhaps realistic-goals. It may focus too much on building a research-oriented and necessarily elite university as the expense of expanding access or serving national needs. It may set up unrealistic expectations that harm faculty morale and performance.

The concept of a world-class university reflects the norms and values of the world's dominant research-oriented academic institutions-especially the United States and the major Western European countries. The idea is based on the German research university that came to dominate academic thinking at the end of the 19th century, especially with the acceptance of this model in the United States, Japan, and other countries. While all of the world's universities are essentially in the Western tradition, the world-class ideal of the research university is a special variation of that tradition. The American sociologist David Riesman observed in the 1950s that U.S. universities were missing out on diverse academic goals and ideas because of a "meandering procession" that almost all were following in an effort to become like Harvard, Berkeley, and a few other key research-oriented institutions. The same criticism can be made now, as universities around the world seem to be orienting themselves to this single academic ideal. Institutions, and nations, need to carefully assess their needs, resources, and long-term interests before launching into a campaign to build world-class institutions.

Universities operate in both national and global contexts. The world-class idea is in the global sphere. It assumes that the university is competing with the best academic institutions in the world and is aspiring to the pinnacle of excellence and recognition. National and even regional realities may be different. They relate to the need of the immediate society and economy and imply responsiveness to local communities. The nature of academic performance and roles may differ when relating to these different contexts. To label one world class while relegating the others to the nether regions of the academic hierarchy is perhaps inevitable, but nonetheless unfortunate. How to relate to these varying realities is not easy, but it is of central importance.

\section{Perspectives}

The debate about world-class higher education is important. Government and academic planners in countries such as China, where several top universities are self-consciously trying to transform themselves into world-class institutions are considering the topic. In other countries, such as in South Korea, people are giving serious attention to the idea. Britain, traditionally the home of a number of top institutions, worries that it is losing its competitive edge.

The world-class debate has one important benefit-it is focusing attention on academic standards and improvement, and on the roles of universities in society, and of how academic institutions can fit in a higher education system within a country and in the global academic universe. Striving for excellence is not a bad thing, and competition may spark improvement. Yet, a sense of realism must be a part of the equation, and sensitivity to the public good as well. The fuzziness of the concept of a world-class university combined with the impossibility, so far at least, of measuring academic quality and accomplishment makes the struggle difficult. Indeed, it might well be the case that the innovative energies and resources of higher education should be focused on more realistic and perhaps more useful goals.

Acknowledgments: This article has benefited from the ideas and writings of Wang Yingjie of Beijing Normal University, Pang Eng Fong and Linda Lim of Singapore Management University, and Henry Rosovsky of Harvard University. I am also indebted to the ideas of Edward Shils, Max Weber, and John Henry Newman concerning the nature of the university.

\section{Internet Resources}

Visit our website for downloadable back issues of International Higher Education and other publications and resources at http://www.bc.edu/cihe/. 